\title{
ANALISIS PENGARUH VARIASI DIAMETER MAIN JET DAN PILOT JET PADA SEPEDA MOTOR SUZUKI FU 150
}

\author{
Adheila Noer Syaief ${ }^{2}$, Anton Kuswoyo ${ }^{2,}$ M. Azhar Amin ${ }^{3}$ \\ ${ }^{1,2,3)}$ Jurusan Mesin Otomotif Politeknik Negeri Tanah Laut \\ J1. A. Yani km 6 Pelaihari Tanah Laut, Kalimantan Selatan \\ ${ }^{1)}$ Email: adhel_syaief@politala.co.id
}

Naskah diterima: 1 Desember 2018 ; Naskah disetujui: 31 Desember 2018

\begin{abstract}
ABSTRAK
Dalam suatu kompetisi atau lomba balap sepeda motor diperlukan suatu sepeda motor yang memiliki tenaga besar guna dapat menjuarai perlombaan tersebut. Salah satunya dengan cara mengganti diameter pilot jet dan main jet pada karburator. Karburator berfungsi mengatur akselerasi (percepatan) pada kecepatan dan beban pada tingkat tertentu penelitian ini bertujuan untuk mengetahui berbagai perbedaan pergantian diameter pilot jet dan main jet karburator terhadap putaran mesin pada motor SUZUKI SATRIA FU 150 dan mengetahui pilot jet dan main jet berapa yang memiliki performa tinggi pada putaran mesin, setelah dilakukan pengujian didapatlah putaran mesin tertinggi $=12750 \mathrm{rpm}$ pada diameter pilot jet 20 dan main jet 125, putaran mesin terendah $=9000$ rpm pada diameter pilot jet 12.5 dan main jet 110. Konsumsi bahan bakar paling hemat = 9,57 menit pada diameter pilot jet 12,5 dan main jet 110, Konsumsi bahan bakar paling boros 5,4 menit pada diameter pilot jet 20 dan main jet 125 .
\end{abstract}

Kata Kunci : pilot jet, main jet, karburator, Suzuki Satria Fu 150

\section{PENDAHULUAN}

Seiring dengan perkembangan jaman yang semakin pesat, manusia senantiasa berlomba-lomba mengembangkan ilmu pengetahuan dan menciptakan penemuan-penemuan baru dibidang ilmu pengetahuan dan teknologi yang semakin canggih dan modern. Penemuan-penemuan teknologi diharapkan akan mempermudah manusia dalam melaksanakan aktifitas hidupnya. Semakin banyak penemuanpenemuan yang dapat diaplikasikan dengan kehidupan sehari-hari maka semakin mudah manusia menjalankan kegiatan sehari-hari untukmencapai apa saja yang diinginkan [1].

Salah satu transportasi darat yaitu sepeda motor. Sepeda motor saat ini menjadi alat transportasi yang sangat menguntungkan. Dengan ukuran lebih kecil, ringan, sepeda motor menjadi alat transportasi yang efisien mampu menempuh jarak jauh, tidak memerlukan banyak tempat untuk parkir dan pemakaian bahan bakar lebih hemat dibandingkan mobil. Sepeda motor merupakan suatu unit, terdiri dari beberapa komponen yang bersatu dan bekerjasama sehingga kendaraan dapat bergerak membawa penumpang dari satu tempat ke tempat yang lain dengan aman. Tenaga motor sangatlah penting karena sebagai sumber kekuatan menjalankan motor serta muatannya sehingga mampu melaju dengan kecepatan tertentu [2].
Motor sendiri terbagi menjadi dua berdasarkan langkah kerjanya. Mesin empat langkah dan mesin dua langkah. Peningkatan putaran mesin khususnya pada mesin dua langkah dapat dilakukan dengan berbagai cara lain: mengganti komponen sepertipiston, ring piston, batang piston, busi, kabel busi, kumparan standar dengan komponen kompetisi (racing), memperhalus lubang isap dan dinding bilas, pemotongan torak, memperbesar silinder, mempersempit ruang bakar, memodifikasi diameter venturi, memperbesar ukuran pilot jet dan main jet, pemasangan klip pada alur bawah katup jarum.

Tujuan utamanya modifikasi-modifikasi tersebut untuk meningkatkan performa mesin sehingga putaran mesin motor tersebut menjadi bertambah dan tenaga motor menjadi bertambah. Dengan peningkatan tenaga dari motor maka akan timbul masalah bahan bakar akan menjadi lebih boros karena mesin memerlukan banyak bahan bakar untuk dapat meningkatkan tenaganya berbeda dibandingkan dengan mesin yang masih standaryang lebih memperhatikan pada aspek efisiensi. Karburator berfungsi mengatur akslerasi (percepatan) pada kecepatan dan beban pada tingkat tertentu, kemudian dapat memudahkan mesin untuk hidup, dapat memberikan tenaga yang besar pada mesin dan kendaraan dapat bekerja dengan ekonomis. Modifikasi venturi dipengaruhi oleh bentuk, diameter dan kehalusan permukaan. Venturi yang mempunyai permukaan kasar bentuk aliran 
udara akan berbeda dengan bentuk aliran udara pada permukaan yang halus.Diameter venturi yang kecil menyebabkan kecepatan udara menjadi cepat yang mengakibatkan tekanannya menjadi rendah sehingga bensin di ruang pelampung akan terisap dan bercampur dengan udara terus terisap ke silinder, tetapi jika venturi terlalu sempit maka tenaga akan semakin berkurang karena suplai udara dan bensin sedikit. Pada diameter venturi yang besar maka kecepatan udara semakin rendah tekanannya semakin tinggi sehingga bensin sulit untuk naik ke ruang venturi yang dapat menyebabkan tenaga motor menjadi berkurang.

Berdasarkan uraian latar belakang, maka dilakukan penelitian dengan judul: "Analisis Pengaruh Pergantian Diameter Main Jet Dan Pilot Jet Karburator Terhadap Putaran Mesin Pada Sepeda Motor Suzuki Satria FU 150”.

\section{METODOLOGI}

\section{Peralatan yang Digunakan}

Adapun peralatan yang digunakan pada penelitian ini adalah sebagai berikut:

1. Obeng minus $(-)$ dan $(+)$

2. Tang

3. Gelas ukur

4. Manifold karet

5. Selang bensin

6. Tangki bahan bakar buatan

\section{Bahan yang Digunakan}

Adapun bahan yang akan digunakan pada penelitian ini adalah sebagai berikut:

1. Karburator sepeda motor SUZUKI SATRIA FU 150

2. Sepeda motor SUZUKI SATRIA FU 1

\section{Diagran Alir}

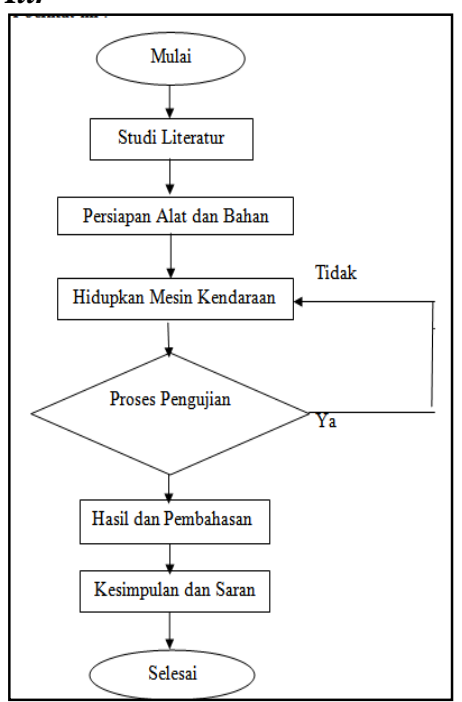

Gambar 1 Diagram Alir

\section{Prosedur Penelitian}

Berikut langkah-langkah perancangan :

1) Persiapan

a. Menyiapkan sampel yang akan digunakan yaitu karburator sepeda motor SUZUKI SATRIA FU 150.

b. Menyiapkan alat dan bahan penelitian.

c. Menghidupkan motor untuk pemanasan selama 2 menit agar mesin mencapai suhu kerja

2) Pelaksanaan Penelitian

a. Memasang karburator dengan diameter pilot jet 12,5dan main jet 110 (standar).

b. Gas diputar penuh untuk mendapatkan angka putaran mesin tertinggi.

c. Mencatat hasil uji coba.

d. Untuk pengambilan data ke-2 mempunyai selang waktu selama 10 menit.

e. Melepas karburatordan digantimain jet 110 dan pilot jet 12,5 menjadi 120 dan 17,5.

f. Gas diputar penuh untuk mendapatkan angka putaran mesin tertinggi.

g. Mencatat hasil uji coba.

h. Melepas karburatordan diganti main jet 120 dan pilot jet 17,5 menjadi 125 dan 20.

i. Gas diputar penuh untuk mendapatkan angka putaran mesin tertinggi.

j. Mencatat hasil uji coba.

\section{Karburator yang Akan Dianalisa}

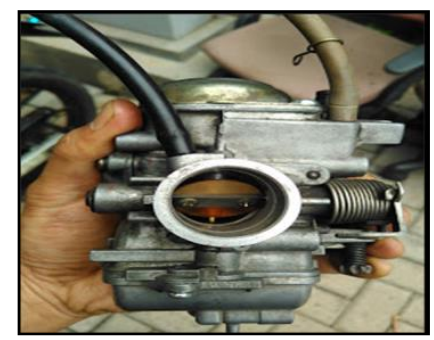

Gambar 2 Karburator

Keterangan

1. Piston karburator

2. Spring

3. Jarum piston karbu

4. Karet vakum

5. Pelampung

6. Mangkok karbu

7. Pilot jet 12,5

8. Main jet 110

9. Nozzle

10. Needle jet

11. Choke Mechanism 


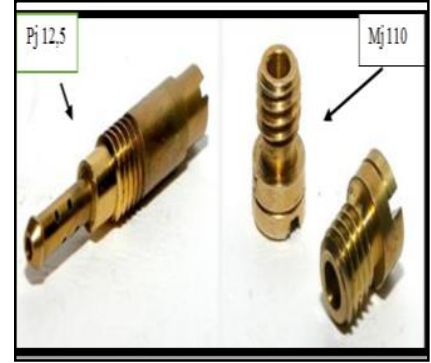

Gambar 3 Main Jet MJ110 dan Pilot Jet PJ 12,5

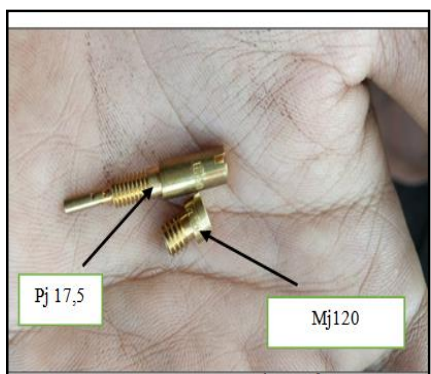

Gambar 4 Main Jet MJ120 dan Pilot Jet PJ17,5

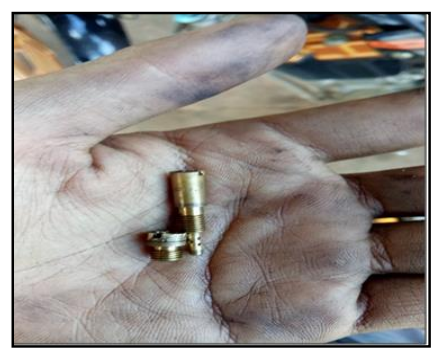

Gambar 5 Main Jet PJ20 dan MJ125

\section{HASIL DAN PEMBAHASAN}

\section{Perbandingan Hasil Pengujian}

Pengujian putaran rpm pada karburator dengan diameter pilot jet 12,5, 17,5, 20dan main jet 110, 120 dan 125 maka didapat hasil seperti pada tabel dibawah ini.

Tabel 1Data Hasil Pengukuran Putaran Mesin

\begin{tabular}{|c|c|c|c|}
\multirow{2}{*}{ No. } & \multicolumn{3}{|c|}{ Data Hasil Pengukuran Putaran (RPM) } \\
\cline { 2 - 4 } & $\begin{array}{c}\text { Pilot jet 12,5 dan } \\
\text { Mainjet 110 }\end{array}$ & $\begin{array}{c}\text { Pilotjet } 17,5 \text { dan } \\
\text { Main jet 120 }\end{array}$ & $\begin{array}{c}\text { Pilotjet 20 dan } \\
\text { Mainjet 125 }\end{array}$ \\
\hline 1. & 9000 & 11000 & 12000 \\
\hline 2. & 9750 & 11500 & 12250 \\
\hline 3 & 9750 & 11250 & 12750 \\
\hline 4. & 9250 & 11500 & 12250 \\
\hline 5. & 9500 & 11500 & 12500 \\
\hline 6. & 9750 & 11750 & 12750 \\
\hline 7. & 9500 & 11250 & 12000 \\
\hline 8. & 9250 & 11000 & 12500 \\
\hline 9. & 9750 & 11500 & 12750 \\
\hline 10. & 9500 & 11750 & 12500 \\
\hline Jumlah & 95000 & 114000 & 124500 \\
\hline $\begin{array}{c}\text { Rata- } \\
\text { rata }\end{array}$ & 9500 & 11400 & 12400 \\
\hline
\end{tabular}

Data hasil pengukuran putaran mesin rpm pada sepeda motor Suzuki Satria FU 150. Seperti telah ditunjukan dalam tabel di atas, di peroleh hasil putaran mesin yang tertinggi $12750 \mathrm{rpm}$ menggunakan diameter pilot jet 20 dan main jet 125 , sedangkan putaran mesin yang terendah $9000 \mathrm{rpm}$ menggunakan diameter pilot jet 12,5 dan main jet 110 (standart).

Pengujian konsumsi bahan bakar pada karburator dengan diameter pilot jet 12,5, 17,5, 20dan main jet 110, 120 dan 125 maka didapat hasil seperti pada tabel dibawah ini.

Tabel 2 Data Hasil Konsumsi Bahan Bakar

\begin{tabular}{|c|c|c|c|c|c|}
\hline \multirow[b]{2}{*}{ No } & \multirow{2}{*}{$\begin{array}{l}\text { Putaran } \\
\text { mesin } \\
(\mathrm{rpm})\end{array}$} & \multirow{2}{*}{$\begin{array}{c}\text { Bahan } \\
\text { bakar } \\
(\mathrm{ml})\end{array}$} & \multicolumn{3}{|c|}{$\begin{array}{c}\text { Hasilwaktu (s) ukuran pilot jet dan } \\
\text { main jet }\end{array}$} \\
\hline & & & 12,5 dan 110 & 17,5 dan 120 & 20 dan 125 \\
\hline 1. & \multirow{10}{*}{4000} & \multirow{10}{*}{100} & 577 & 432 & 324 \\
\hline 2. & & & 572 & 434 & 327 \\
\hline 3. & & & 568 & 430 & 321 \\
\hline 4. & & & 568 & 429 & 328 \\
\hline 5. & & & 577 & 435 & 320 \\
\hline 6. & & & 573 & 428 & 325 \\
\hline 7. & & & 575 & 436 & 323 \\
\hline 8. & & & 569 & 425 & 324 \\
\hline 9. & & & 574 & 439 & 326 \\
\hline 10. & & & 576 & 431 & 322 \\
\hline \multicolumn{3}{|c|}{ Jumlah } & 5729 & 4319 & 3240 \\
\hline \multicolumn{3}{|c|}{ Rata-rata detik } & 572,9 & 431,9 & 324 \\
\hline \multicolumn{3}{|c|}{ Rata-rata menit } & 9,57 & 7,2 & 5,4 \\
\hline
\end{tabular}

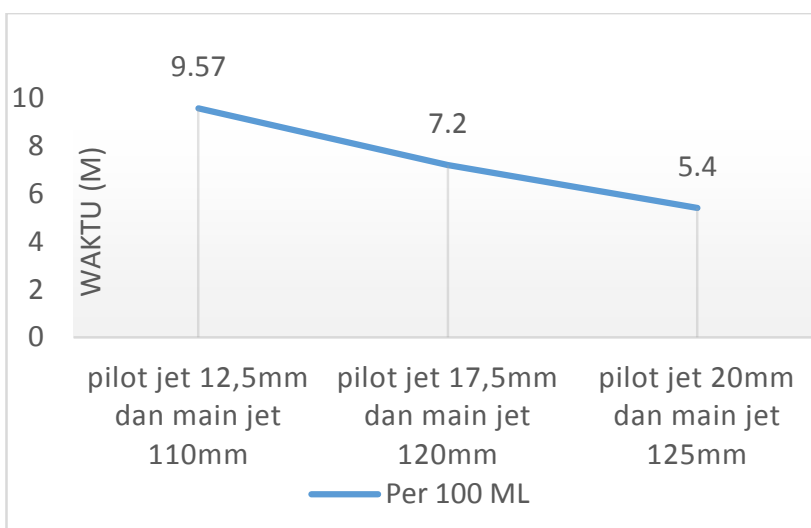

Gambar 5 Grafik Rata-rata Konsumsi Bahan Bakar 
Pada Gambar grafik 4.1 dapat dilihat adanya perbedaan angka konsumsi bahan bakar pada masing-masing karburator dalam setiap $100 \mathrm{ml}$ bahan bakar dan putaran mesin 4000rpm yang diakibatkan berbedanya ukuran pilot jet dan main jet dari karburator tersebut. Dapat dilihat juga adanya perbedaan waktu pada setiap pengujiannya, terlihat sebanyak 10 kali pengujian setiap kali pengujian memiliki nilai waktu yang berbeda-beda hal itu mungkin diakibatkan karena kurang ketelitian pada instrument alat ukur bahan bakar sehingga perbedaan sedikit saja jumlah bahan bakaryang digunakan akan berpengaruh terhadap waktu yang didapat. Semakin besar diameter pilot jet dan main jet maka suplai bahan bakar semakin banyak, sebaliknya semakin kecil diameter pilot jet dan main jet maka semakin sedikit juga suplai bahan bakar. Selain itu penggunaan main jet dan pilot jet dengan ukuran besar dapat meningkatkan putaran mesin.

\section{KESIMPULAN}

1. Penggunaan main jet dan pilot jet yang berdiameter lebih besar akan meningkatkan putaran mesin menjadi lebih tinggi.Ini dapat dilihat pada hasil uji analisis data yang menyatakan bahwa pada penelitian ini didapatkan putaran mesin tertinggi $=12750 \mathrm{rpm}$ pada diameter pilot jet 20 dan main jet 125 , putaran mesin terendah $=9000 \mathrm{rpm}$ pada diameter pilot jet 12.5 dan main jet 110

2. Pengaruh pergantian diameter pilot jetdan main jetterhadap konsumsi bahan bakar dapat disimpulkan bahwa konsumsi bahan bakar paling irit adalah saat menggunakan main jet dan pilot jet standart. Sedangkan untuk putaran mesin yang lebih tinggi adalah saat menggunaklan main jet dan pilot jet yang berdiameter lebih besar.Halini disebabkan karena pergantian diameter pilot jet dan main jetakan berpengaruh terhadap kecepatan aliran udara di karburator yang berpengaruh terhadap bahan bakar yang masuk ke silinder, sehingga akan mempengaruhi konsumsi bahan bakar. Dengan pembesaran diameter pilot jet dan main jetmaka aliran udara di karburator akan lebih cepat yang mengakibatkan putaran mesin lebih tinggi jika dibandingkan dengan pengecilan diameter pilot jet dan main jet.

\section{DAFTAR PUSTAKA}

[1] Herwendra. (2004). Pengaruh Pergantian Pilot jet dan main jet Karburator Pada Sepeda Motor Yamaha F1ZR Tahun 2001. Surakarta : Universitas Sebelas Maret
[2] Karyono, M. (2012). Di Balik Booming Industri Sepeda Motor. Diperoleh 17 Februari 2012 